\title{
Beyond Belief
}


This page intentionally left blank 


\section{Robert N. Bellab}

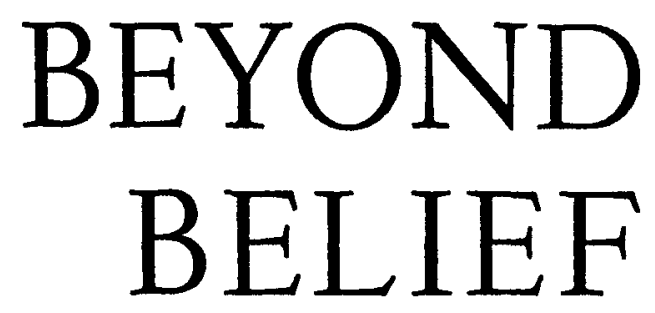

Essays on Religion in a Post-Traditional World

University of California Press

Berkeley - Los Angeles - London 
University of California Press

Berkeley and Los Angeles, California

University of California Press, Ltd.

London, England

First California Paperback Printing 1991

0 1970 by Robert N. Bellah

Library of Congress Cataloging-in-Publication Data

Bellah, Robert Neelly, 1927-

Beyond belief : essays on religion in a post-traditional world /

Robert N. Bellah.

p. cm.

Reprint. Originally published: New York : Harper \& Row, 1970.

Includes bibliographical references and index.

ISBN 978-0-520-07394-4

1. Religion and sociology. 2. Religion and culture. I. Title.

BL60.B37 1991

$306.6-\mathrm{dc} 20$

Printed in the United States of America

$\begin{array}{llll}10 & 09 & 08 & 07\end{array}$

$\begin{array}{llllll}12 & 11 & 10 & 9 & 8 & 7\end{array}$

The paper used in this publication is both acid-free and totally chlorine-free (TCF).

It meets the minimum requirements of ANSL/NISO Z39.48-1992 (R 1997)

(Permanence of Paper). () 